valjutnogo rynku ta dijal'nist' bankiv. Visnyk Nacional'nogo banku Ukrai'ny, 5, 26-33.

5. Ivasiv, I. B., Kornyljuk, R. V. (2011). Vplyv inozemnyh bankiv na bankivs'ku systemu Ukrai'ny. Visnyk Nacional'nogo banku Ukrai'ny, 10, 84-91.

6. Nacional'nyj bank rozshyryv kryterii' vyznachennja bankiv, shho nalezhat' do inozemnyh bankivs'kyh grup. NBU. Available at: http://www.bank.gov.ua/control/uk/publish/ article?art_id $=25673128$

7. Pokaznyky finansovoi' zvitnosti bankiv Ukrai'ny (2013-2015 rr.). NBU. Available at: https://bank.gov.ua/ control/uk/\%20 publish/category?cat_id $=64097$
8. Rejting ustojchivosti bankov po itogam 1 kvartala 2016. Minfin. Available at: http://minfin.com.ua/banks/ rating/?gclid=Cj0KEQjw2ua8BRDeusOk15qth4QBEiQA8BpQ cMSN58aXEZxlUtEAKCUIdE73TTKy_eOvcquRqyzK_GAaA s8k8P8HAQ

9. Rejting zhiznesposobnosti ukrainskih bankov-2016. Forbes Ukraina. Available at: http://forbes.net.ua/magazine/ forbes/1409877-rejting-zhiznesposobnosti-ukrainskih-bankov2016

10. Rejting samyh nadezhnyh bankov Ukrainy v 2016 godu. Forinshurer - strahovanie v Ukraine. Available at: $\mathrm{http} / / /$ forinsurer.com/rating-banks

Дата надходження рукопису 19.07.2016

Вовчак Ольга Дмитрівна, доктор економічних наук, професор, завідувач кафедри, кафедра банківської справи, Державний вищий навчальний заклад «Університет банківської справи», вул. Андріївська, 1, м. Київ, Україна, 04070

E-mail: vovchak.olga@meta.ua

Миськів Галина Василівна, кандидат економічних наук, доцент, кафедра фінансів, Навчально-науковий інститут підприємництва та передових технологій Національного університету «Львівська політехніка», вул. Горбачевського, 18, м. Львів, Україна, 79044

E-mail: galinamyskiv@gmail.com

UDC 614.2(477):33

DOI: $10.15587 / 2313-8416.2016 .76236$

\title{
HEALTH ECONOMICS MODERN ASPECTS IN GERMANY
}

\section{(c) M. Korsunska}

In this article, I researched contemporary experience and aspects of health economics in Germany. Considered the history of the formation of social policy in Germany and partly outlined the issues of health economics. Graphically depicted the system of public health and health economics institute. I recommended that further studies are needed to explore and implement German Practice in Ukraine and other European countries

Keywords: social policy, health economics, Germany, social protection, health care, health insurance, healthcare industry

У роботі досліджено сучасний досвід та аспекти економіки здоров'я в Німеччині. Розглянуто історію формування соціальної політики в Німеччині і частково викладені питання економіки охорони здоров'я. Графічно зображена система інституту суспільної охорони здоров'я та економіки здоров'я. Визначили, щчо необхідні подальші дослідження для реалізації німецької практики в Україні та інших краӥнах Свропи

Ключові слова: сочіальна політика, економіка здоров'я, Німеччина, соціальний захист, охорони здоров'я, медичне страхування, медична промисловість

\section{Introduction}

The social policy aims to protect against distress, to safeguard against the vicissitudes of life and advanced society stage on curb social inequalities. It includes the guarantee of a minimum subsistence. The activity of the state to the person in risks and vicissitudes of life, in particular against specific risks as a result of old age, disability, illness, unemployment, care in case of the death. Not only from an economic but from educational, psychological, legal, hygienic and ethical considerations; but public policy objectives such as social justice, reduce inequality, the increase of his welfare of the whole society. The promotion of self-help and self-regulatory capacity are social policy objectives. The processing of concrete risk situations as a task area of social policy and said basic welfare state goal orientations are interdependent and belong together.

Health Economics is part of social policy, but not in all countries it is implemented and applied. And since Germany in this aspect is advanced country (not only in Europe but the whole world) therefore appropriate to examine current experience and the situation of health economics in Germany.

\section{Literature review}

Health economics in Germany can be considered as a collective term for all activities that have anything to do with health in this country. This interpretation done by Andreas Goldschmidt in 2002 seems, however, very generous due to several overlaps with other economic 
sectors. A simple outline of the area of health in three areas provides an "onion model of health care economics" by Elke Dahlbeck and Josef Hilbert from "Institut Arbeit und Technik (IAT)" at the University of Applied Sciences Gelsenkirchen: Core area is the ambulatory and inpatient acute care and geriatric care, and health administration. Around it is located wholesale and supplier sector with the pharmaceutical industry, medical technology, healthcare, and wholesale trade of medical products. Health-related margins are the fitness and spa facilities, assisted living, and health tourism. Significant contributions to the development of the theory and practice of modern health economy in Germany have been made by following scientists: Jesse B [1], Josef Hilbert [2], Neumann K. [3].

So far there are no Ukrainian scientists who are working on studying and implementation of German experience in the field of health economics. I've found that there is need to explore the theory and practice of modern health economy in Germany.

\section{Aim and research problems}

Aim - to study current experience and the situation of health economics in Germany.

Research problems:

- Historical formation of social security and health economics in Germany.

- Graphical structure of current health care system and social security in Germany.
- Statistical information about health economics in Germany for recent years.

4. The formation, development and present state of health economics in Germany

Following five tables provides a historical survey of the development of social protection in Germany (Table 1-5). It is based on the realization that the modern, complex "system" of social welfare is an "evolved" one and can be best understood by knowing how it came into being. It has layers of historical growth and is a far cry from the kind of rigor one expects of «systems» in the scientific or philosophical sense. But in the professional discourse of social theory and social law it may be referred well to as a "system," and this can be useful to the historian if it is asked to specify the past phenomena searching for and in which it expects to find a bridge to the present. Of course, a look back at history can be useful also in that can provide today's actors clues to how much of the past is preserved in the various structures that exist today. If something should or must be changed, it pays to examine the long-term developmental trends. Many declarations of political intent and reform projects have failed simply because they underestimated the inertia of historically evolved material. Long-term trends can be reversed only if one has detailed knowledge about the forces driving them. In this limited sense, historical information - in conjunction with sociological, economic, and legal frameworks can also serve to lay the groundwork for innovations [4].

Development of the German welfare state model from Prussian Law until 1945

\begin{tabular}{|c|c|c|c|}
\hline & disease & unemployment & Age (poverty) \\
\hline 1794 & \multicolumn{3}{|c|}{$\begin{array}{c}\text { General Prussian Land Law } \\
\text { - Inter alia State obligation to supply the needy }\end{array}$} \\
\hline 1845 & \multicolumn{3}{|c|}{$\begin{array}{c}\text { General Prussian Trade Regulations } \\
\text { - Inter alia abolition of guild privileges, associate mandatory insurance requirement for Community, } \\
\text { cash also for factory workers }\end{array}$} \\
\hline 1871 & \multicolumn{3}{|c|}{ Founding of the German Empire } \\
\hline 1876 & $\begin{array}{l}\text { Act on registered Relief Fund } \\
\text { (1874: approximately } 10,000 \\
\text { Relief Fund) }\end{array}$ & & \\
\hline 1878 & \multicolumn{3}{|c|}{ Socialist law } \\
\hline 1881 & \multicolumn{3}{|c|}{$\begin{array}{l}\text { Kaiser Imperial «Botschaft» from 17/11/1881 } \\
\text { (laws to improve the social protection of workers)Insurance against industrial accidents (statutory accident } \\
\text { insurance) restructuring of the health insurance system (statutory health insurance) age and debilitating con- } \\
\text { dition (statutory pension insurance) }\end{array}$} \\
\hline 1883 & Statutory health insurance & & \\
\hline 1884 & Statutory accident insurance & & \\
\hline 1889 & & & $\begin{array}{c}\text { Statutory pension insurance for } \\
\text { workers } \\
\end{array}$ \\
\hline 1911 & Merging o & cial legislation in the Reich Insuran & Code (RVO) \\
\hline 1927 & & $\begin{array}{l}\text { Law about employment and unem- } \\
\text { ployment }\end{array}$ & \\
\hline $\begin{array}{l}1933 \\
1945\end{array}$ & Abolition of & tomy over management of surpluses & the Reich budget \\
\hline
\end{tabular}


Table 2

Reconstruction and the "economic miracle" (1945 and 1969)

\begin{tabular}{|c|c|c|}
\hline 1949 & \multicolumn{2}{|c|}{$\begin{array}{c}\text { Founding of the Federal Republic of Germany } \\
\text { - Welfare state bid (Art, 1, 20, 28 Basic Law) - "reconstruction" of social security }\end{array}$} \\
\hline 1955 & $\begin{array}{l}\text { Act Kassenarzt law } \\
\text { - Ensuring KVn - }\end{array}$ & \\
\hline 1957 & $\begin{array}{c}\text { Sick Pay Act (workers) } \\
\text { (In the first } 6 \text { weeks } 65 \% \text { AG, to } 90 \% \text { SHI) }\end{array}$ & $\begin{array}{c}\text { pension reform } \\
\text { - Revitalize pensions } \\
\text { - Reference: Current }\end{array}$ \\
\hline 1959 & $\begin{array}{l}\text { Draft Law on the reorganization of the health insurance } \\
\text { - failed }\end{array}$ & \\
\hline 1961 & $\begin{array}{l}\text { Federal Social Welfare Act } \\
\text { - Aid in special situations }\end{array}$ & \\
\hline 1966 & $\begin{array}{l}\text { change of government } \\
\text { (Of the CDU/CSU+FDP coalition to the CDU }\end{array}$ & tion) \\
\hline 1969 & Sick Pay Law (100\% AB in the first 6 weeks) & \\
\hline
\end{tabular}

Development of social welfare (1969-1976)

\begin{tabular}{|c|c|c|}
\hline 1969 & \multicolumn{2}{|c|}{ change of government (Of the CDU/CSU+SPD coalition with the SPD+FDP coalition) } \\
\hline 1970 & $\begin{array}{l}1970 \text { Second Health Insurance Amendment Act } \\
\text { - Raising the contribution assessment ceiling to } 75 \% \text { of GRV } \\
\text { - Revitalize the contribution assessment ceiling }\end{array}$ & \\
\hline 1972 & 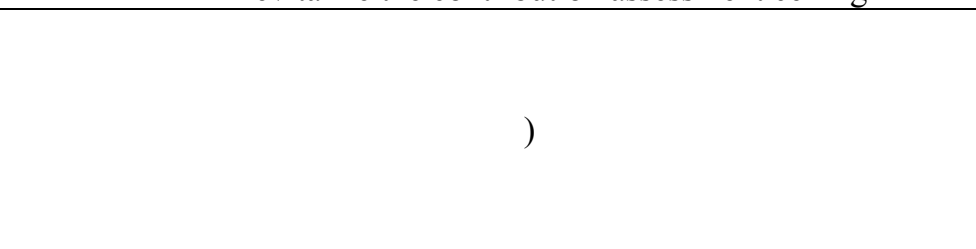 & $\begin{array}{c}\text { Pension reform law } \\
\text { - Opening of new groups } \\
\text { (eg self-employed) } \\
\text { - Flexible age limit } \\
\text { - Forward the pensions } \\
\text { other adjustment }\end{array}$ \\
\hline 1972 & Hospital Financing Act (KHG 1972) & \\
\hline 1973 & $\begin{array}{l}\text { An ordinance that regulates the allowances for stationary and } \\
\text { semi-residential care services in hospitals in Germany. (BPflV 1973) }\end{array}$ & \\
\hline 1973 & $\begin{array}{c}\text { Performance Improvement Act } \\
\text { Maid service for hospital care } \\
\text { Dissolution of reimbursement for hospital treatment } \\
\text { Sickness benefits in case of illness of a child }\end{array}$ & \\
\hline 1975 & Social Code (SGB) Book One General Part & \\
\hline
\end{tabular}

Conversion and cost containment (1977-1997)

\begin{tabular}{|c|c|c|}
\hline \\
\hline 1977 & $\begin{array}{c}\text { Health Insurance Cost Containment Act } \\
\text { - Inter alia payments (drugs DM } 1 \text { per agent, } \\
\text { driving costs } 3.50 \text { DM deductible, dentures grant } 80 \% \text { ) }\end{array}$ & $\begin{array}{l}\text { 20. Pension Adjustment Act } \\
\text { Shift of the pension increase } \\
\text { Reduction of contributions for } \\
\text { the KVdR }\end{array}$ \\
\hline 1981 & $\begin{array}{c}\text { Hospital- } \\
\text { Cost containment law }\end{array}$ & \\
\hline 1982 & $\begin{array}{c}\text { Health Insurance cost containment } \\
\text { Amendment Act } \\
\text { Increasing cost-sharing } \\
\text { (Drugs 1.50 DM, travel expenses 5 DM) }\end{array}$ & \\
\hline 1982 & change of government (Of the SPD / FDP coalition to coalition of Cl & U / CSU and FDP)) \\
\hline 1984 & $\begin{array}{c}\text { Hospital- } \\
\text { Restructuring Act (KHNG) } \\
\end{array}$ & \\
\hline 1986 & $\begin{array}{l}\text { An ordinance that regulates the allowances for stationary and semi-residential } \\
\text { care services in hospitals in Germany. (BPflV 1986) }\end{array}$ & \\
\hline 1989 & Health Reform Law (GRG 1989) & Pension reform law 1992 \\
\hline 1993 & Health Care Structure Act (GSG 1993) & \\
\hline 1995 & care Insurance Act & \\
\hline $\begin{array}{l}1995 \\
1997\end{array}$ & "Third Stage" of health reform & \\
\hline
\end{tabular}


Table 5

\begin{tabular}{|c|c|c|c|}
\hline \multicolumn{4}{|c|}{ 'Modernization' of the welfare state (1998 - till present) } \\
\hline 1998 & \multicolumn{3}{|c|}{$\begin{array}{c}\text { change of government } \\
\text { (Of the CDU/CSU+FDP coalition to coalition SPD+Alliance 90/DIE GRUNEN) }\end{array}$} \\
\hline 1998 & Solidarity Support Act & & \\
\hline 2000 & $\begin{array}{c}\text { SHI Reform Act } \\
2000 \\
\text { (Integrated care, DRG, strengthening of primary care physi- } \\
\text { cians, etc.) }\end{array}$ & & $\begin{array}{c}\text { pension reform } \\
\text { (From the pay as you go to private } \\
\text { provision and funding) }\end{array}$ \\
\hline 2002 & DRG law (FPG) & & $\begin{array}{l}\text { complete restructuring of } \\
\text { the pay system for hospitals }\end{array}$ \\
\hline 2002 & \multicolumn{3}{|c|}{ Federal Elections } \\
\hline 2004 & $\begin{array}{l}\text { The "big health reform" } \\
\text { The Modernization Act (GMG) }\end{array}$ & & \\
\hline 2005 & \multicolumn{3}{|c|}{ Federal Elections and change of government (grand coalition CDU/CSU+SPD) } \\
\hline 2007 & $\begin{array}{l}\text { Health Reform: SHI (Act for strengthening competition in } \\
\text { public health insurance), partly with effect from } 2009 \\
\text { (Health Fund) }\end{array}$ & & \\
\hline 2007 & Care Further Development Act (SGB XI) & & \\
\hline 2007 & GKV- Act to Promote Competition & $\begin{array}{l}\text { Introduction } \\
\text { health Funds }\end{array}$ & $\begin{array}{l}\text { RVAge Limit Adjustment Act } \\
\text { (SGB VI) }\end{array}$ \\
\hline 2009 & $\begin{array}{l}\text { Reorganization Hospital Financing Act and } \\
\text { Hospital Remuneration Act }\end{array}$ & & \\
\hline 2009 & \multicolumn{3}{|c|}{ Federal Elections (CDU/CSU FDP coalition + ) } \\
\hline 2011 & GKV- financing Act & & \\
\hline 2013 & Care realignment law (PNG) & & \\
\hline
\end{tabular}

The most general and stable observation of the historical development of protections against typical social risks reveals a direct dependence of these protections on the respective ways in which people associate to form a society. Specific societal forms give rise to specific protections to care for children and the old, the sick and the disabled, the poor or the victims of accidents - or occasionally even to expel them. The important factors are climate and other geographic conditions, the level of the national product, societal-political structures, the degree of education, the extent to which exchange transactions are monetarized, and much more [4]. Nowhere are so many social benefits offered and consumed as in the affluent northern-western countries of the world, while about a third of humanity lives on less than a dollar a day and German experience, therefore, is important to study further (Fig. 1).

The German health care industry has a significant economic importance for Germany. The health expenditure amounted in 2013 to around 315 billion euros - the equivalent of 3,910 euros per inhabitant and a share of 11.2 percent of the gross domestic product. In the core area of the healthcare industry, $70 \%$ of spending by the social security systems are financed. But the SHI expenditures amounted to 2013 rd year. 194 billion euros (2012: EUR 185 billion). The share of private health insurance of health expenditure amounted in 2012 to approx. 28 billion euros. In the second healthcare market flow almost 76 billion euros in consumer spending (according to 2014) [5].

The healthcare industry is a growth industry to expand. Their gross value is annually increased from 2007 to 2013 by an average of 3.5 percent - significantly faster than the overall economy with 2.4 percent growth [5].

With a comprehensive entitlement for the nearly 70 million legal and approximately 9 million private health insurance agencies and with highly trained professionals and good infrastructure provides Germany as the largest European market excellent location conditions for service providers and companies in the healthcare industry. The health care market is characterized mainly by the development of high-tech products in medical technology, innovative drugs, new treatments and new forms of care [6-10].

Also regarding efficiency and quality of medical care, the German health care in international comparison is doing well: Germany has one of the best health care systems with a comprehensive service catalog, open access to care and lowers deductible. Regardless of income or insurance status is medical assistance outside of regular office hours much easier to obtain than in most other health systems in the world. 


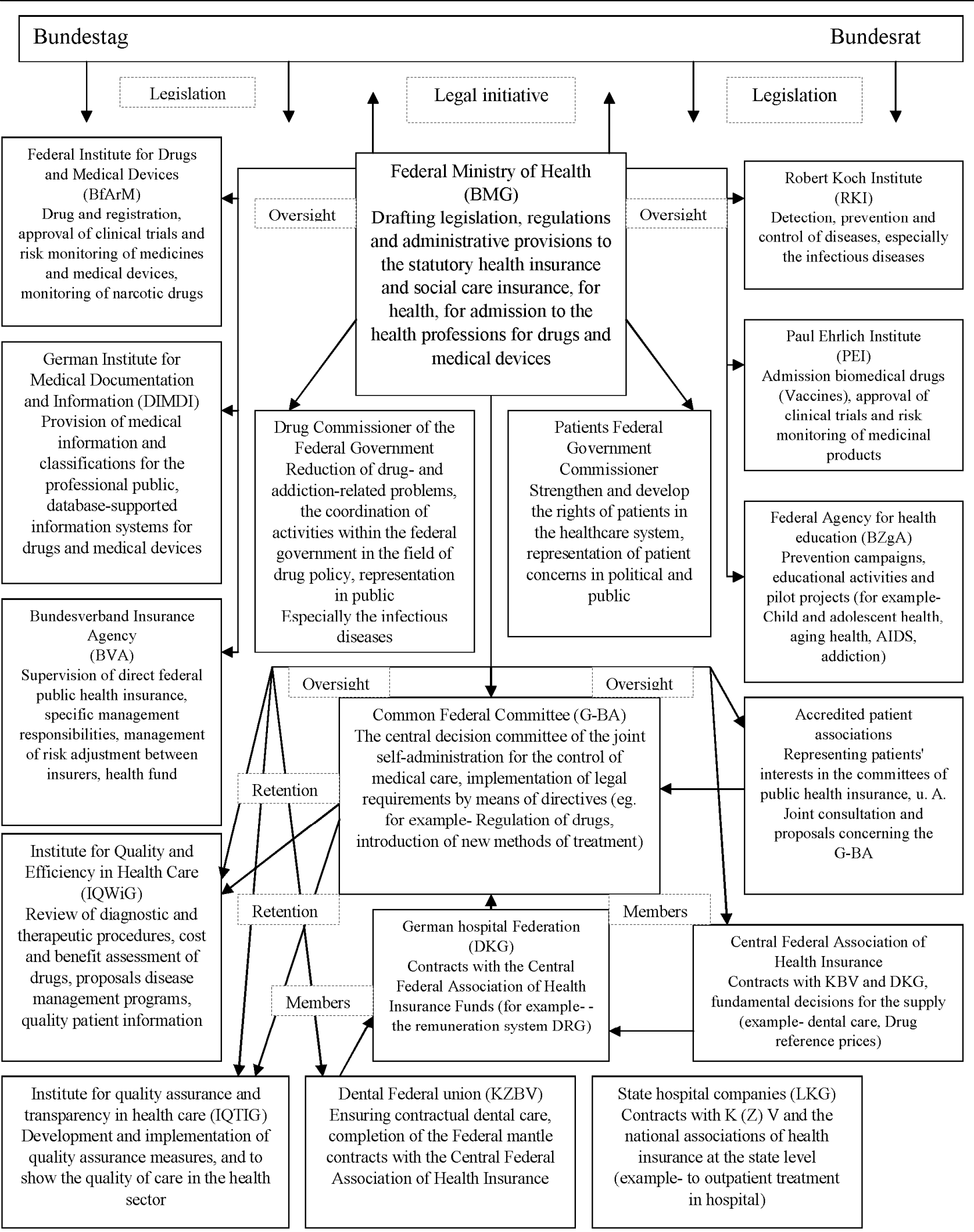

Fig. 1. The health care system and social security in Germany

\section{Results of the research}

I have studied the Historical formation of social security and health economics in Germany and found that formation still going and state changing according to changing economical and social situation in Germany.

I have presented current health care system and social security structure in Germany graphically and found that this structure is still in a dynamic and continue to change. I have overviewed the statistical information about health economics in Germany for recent years and concluded that there is a need for further studies.

\section{Conclusion}

It is often noted that spending on health care, the economy, and the workforce burdened with high costs. This view neglects that a good health care on 
the economic importance of the health sector also simultaneously has a high economic benefit. Because a health care system with good medical acute care and a developed Rehabilitation is good for the economy. It makes a significant contribution that the work capacity and productivity of the workforce is maintained, and people can make itself under its power for their maintenance. Investment in people's health is, therefore, an important contribution to growth, employment, and prosperity.

The topic which we have studied is expedient to investigate in the further studies since demographic development in Germany, the advances in medical technology and the growing health awareness in the population result in an additional demand for conventional professional services in the fields of health, care, and support, as well as of products and services of the second health market. Healthcare industry is offering a variety of opportunities for growth and new jobs; promoting innovation today and in future.

\section{References}

1. Bump, J. B. The long road to universal health coverage. A century of lessons for development strategy [Text] / J. B. Bump. - Seattle, 2010. - 73 p. - Available at: http://www.paho.org/forocoberturagt2014/wp-

content/uploads/2014/08/DIM-The-Long-Road-to-UHC.pdf

2. Hilbert, J. Von der Last zur Chance - Der Paradigmenwechsel vom Gesundheitswesen zur Gesundheitswirtschaft [Text] / J. Hilbert // Gesundheitswirtschaft in Deutschland: die Zukunftsbranche. - WIKOM Wegscheid, 2009. - P. 20-42.

3. Henke, K.-D. Erstellung eines Satellitenkontos für die Gesundheitswirtschaft in Deutschland [Text] / K.-D. Henke, A. Georgi, J. Bungenstock, K. Neumann, M. Baur, S. Ottmann et. al. // Forschungsprojekt im Auftrag des Bundesministeriums für Wirtschaft und Technologie. - 2010. doi: 10.5771/ 9783845223704

4. Stolleis, M. Origins of the German Welfare State: Social Policy in Germany to 1945 [Text] / M. Stolleis // Origins of the German Welfare State. - Springer-Verlag Berlin Heidelberg, 2013. - P. 23-176. doi: 10.1007/978-3-642-22522-2 2

5. Gesundheitswirtschaft im Überblick [Electronic resource]. - Gesundheitswirtschaft im Überblick Bundesministerium für Gesundheit. - Available at: http://www.bmg.bund.de/ themen/gesundheitswesen/gesundheitswirtschaft.html

6. Henke, K.-D. Erstellung eines Satellitenkontos für die Gesundheitswirtschaft in Deutschland [Text] / K.-D. Henke, A. Georgi, J. Bungenstock, K. Neumann, M. Baur, S. Ottmann et. al. // Forschungsprojekt im Auftrag des Bundesministeriums für Wirtschaft und Technologie. - 2010. doi: 10.5771/97838 45223704
7. Henke, K.-D. Neue Berufe im Zweiten Gesundheitsmarkt? [Text] / K.-D. Henke // Public Health Forum. 2008. - Vol. 16, Issue 1. doi: 10.1016/j.phf.2008.01.005

8. Henke, K.-D. Der zweite Gesundheitsmarkt [Text] / K.-D. Henke // Public Health Forum. - 2009. - Vol. 17, Issue 3. doi: 10.1016/j.phf.2009.06.009

9. Henke, K. Von der qualitativen zur quantitativen Erfassung der Gesundheitswirtschaft in Gesundheit beobachten [Text] / K. Henke. - Nutzung, 2009. - P. 167.

10. Ranscht, A. Die Gesundheitswirtschaft - ein Wachstums- und Beschäftigungstreiber? [Text] / A. Ranscht, D. A. Ostwald // Gesundheit und Wirtschaftswachstum. 2010. - P. 31-47. doi: 10.1007/978-3-642-11585-1_3

\section{References}

1. Bump, J. B. (2010). The long road to universal health coverage. A century of lessons for development strategy. Seattle, 73. Available at: http://www.paho.org/forocoberturagt2014/wpcontent/uploads/2014/08/DIM-The-Long-Road-to-UHC.pdf

2. Hilbert, J. (2009). Von der Last zur Chance - Der Paradigmenwechsel vom Gesundheitswesen zur Gesundheitswirtschaft. Gesundheitswirtschaft in Deutschland: die Zukunftsbranche. WIKOM Wegscheid, 20-42.

3. Henke, K.-D., Georgi, A., Bungenstock, J., Neumann, K., Baur, M., Ottmann, S. et. al. (2010). Erstellung eines Satellitenkontos für die Gesundheitswirtschaft in Deutschland. Forschungsprojekt im Auftrag des Bundesministeriums für Wirtschaft und Technologie. doi: 10.5771/9783845223704

4. Stolleis, M. (2013). Origins of the German Welfare State: Social Policy in Germany to 1945. Origins of the German Welfare State. Springer-Verlag Berlin Heidelberg, 23-176. doi: 10.1007/978-3-642-22522-2_2

5. Gesundheitswirtschaft im Überblick. Gesundheitswirtschaft im Überblick Bundesministerium für Gesundheit. Available at: http://www.bmg.bund.de/themen/gesundheits wesen/gesundheitswirtschaft.html

6. Henke, K.-D., Georgi, A., Bungenstock, J., Neumann, K., Baur, M., Ottmann, S. et. al. (2010). Erstellung eines Satellitenkontos für die Gesundheitswirtschaft in Deutschland. Forschungsprojekt im Auftrag des Bundesministeriums für Wirtschaft und Technologie. doi: 10.5771/9783845223704

7. Henke, K.-D. (2008). Neue Berufe im Zweiten Gesundheitsmarkt? Public Health Forum, 16 (1). doi: 10.1016/ j.phf.2008.01.005

8. Henke, K.-D. (2009). Der zweite Gesundheitsmarkt. Public Health Forum, 17 (3). doi: 10.1016/j.phf.2009.06.009

9. Henke, K. (2009). Von der qualitativen zur quantitativen Erfassung der Gesundheitswirtschaft in Gesundheit beobachten. Nutzung, 167.

10. Ranscht, A., Ostwald, D. A. (2010). Die Gesundheitswirtschaft - ein Wachstums- und Beschäftigungstreiber? Gesundheit Und Wirtschaftswachstum, 31-47. doi: 10.1007/ 978-3-642-11585-1_3

Рекомендовано до публікації д-р екон. наук Черниш I. В. Дата надходження рукопису 20.07.2016

Korsunska Maryna, Postgraduate student, Department of Tourism and Administration, Poltava National University named after Yuri Kondratyuk, Pershotravnevyi ave., 24, Poltava, Ukraine, 36011

E-mail: Korsunskamaryna13@gmail.com 